\title{
INFORMÁLIS TUDÁSMEGOSZTÁS
}

- A MUNKAHELYI PLETYKA

INFORMAL KNOWLEDGE SHARING

- GOSSIP IN WORKPLACES

A tudásmegosztás problémája a tudásmenedzsment-rendszerek kutatásának kezdeti fázisától számtalan vizsgálatnak adott teret. A tudásmegosztás eszközeinek sokszínűsége elsősorban a formális megosztási lehetőségek területén indukált kutatásokat, ugyanakkor kevesebb figyelem jut az informális tudásmegosztás módszereinek. A kutatás célja kideríteni, milyen mértékben jellemző az informális tudásmegosztás egy kevéssé kutatott formájának - nevezetesen a munkahelyi pletyka - használata szervezeti keretek között, és milyen hatásával kell számolni a szervezeti folyamatokban. A kutatás során a szerzők egy kiinduló modellt állítottak fel az informális tudás/információátadás folyamatának lekövetésére, melynek érvényességét teszteli a vizsgálat kvantitatív formában, kérdőíves lekérdezés segítségével, 310 válaszadó bevonásával. Az értékelés SPSS programmal (érintettségi index, regressziós modell) történt. Az eredmények azt mutatják, hogy a pletyka minden esetben jelen van, különböző intenzitással, függetlenül a személyes és szervezeti jellemzőktől. Hatása negatív módon érinti a szervezeti kultúrát, a csapatmunkát, a dolgozói karriert. A hamis információk különösen a kommunikációt, a csapatmunkát és a szervezeti teljesítményt befolyásolják.

Kulcsszavak: érintettségi index, informális tudásmegosztás, munkahelyi pletyka, személyes információ, regressziós modell

The problem of knowledge sharing has led to numerous studies from the early stages of research on knowledge management systems. The diversity of knowledge-sharing tools has induced research primarily in the area of formal sharing possibilities; at the same time, less attention has been paid to the methods of informal knowledge sharing. The aim of our research is to investigate the extent to which the use of a less-researched form of informal knowledge sharing-namely workplace gossip -is typical within an organisational framework and the impact it may have upon organisational processes. As part of the research, we set up a baseline model for tracking the process of informal knowledge/information transfer, the validity of which was tested in quantitative form with the help of a questionnaire survey with 310 respondents. The evaluation was performed using the SPSS programme (exposure index, regression model, etc.). The results show that gossip is present in all cases, at different intensities, regardless of personal and organisation characteristics. Its impact has a negative effect on organisational culture, teamwork and employee careers. In particular, false or fake information affects communication, teamwork and organisational performance.

Keywords: exposure index, informal knowledge sharing, personal information, regression model, workplace gossip

\section{Finanszírozás/Funding:}

A szerzők a tanulmány elkészítésével összefüggésben nem részesültek pályázati vagy intézményi támogatásban. The authors did not receive any grant or institutional support in relation with the preparation of the study.

\section{Szerzők/Authors:}

Dr. Bencsik Andrea, egyetemi tanár, Pannon Egyetem, (bencsik.andrea@gtk.uni-pannon.hu)

Dr. Juhász Tímea, tudományos főmunkatárs, Budapesti Gazdasági Egyetem, (juhasz.timea@uni-bge.hu)

A cikk beérkezett: 2019. 08. 07-én, javítva: 2020. 02. 29-én, elfogadva: 2020. 04. 14-én.

This article was received: 07. 08. 2019, revised: 29. 02. 2020, accepted: 14. 04. 2020. 
A tudásmenedzsment (TM) logikájának és módszereinek beépülése a szervezeti folyamatokba ma már elfogadott. Számos kutatás központi kérdése a TM-folyamat leginkább kritikus lépése, nevezetesen a tudásmegosztás (Bencsik, 2015). Nem csak a hazai vizsgálatok, de nemzetközi tapasztalatok is megerősítik azt a tényt, hogy az emberek nem szívesen adják át tudásukat, nem szeretik megosztani a fontos információkat (Boer, 2005; Azudin, Ismail \& Taherali, 2009). A legtöbb esetben a tudásátadással összefüggésben - szervezeti keretek között - a formális megoldások lehetőségei kötik le a vezetők és kutatók figyelmét (Edvinsson, 2006; Csillag, Csizmadia, Hidegh \& Szászvári, 2020). Ugyanakkor, a kutatások azt mutatják, hogy a szakmai információk, a tudás sokszor inkább kötetlen formában terjed és egyéb szakmai vagy személyes információ megosztás is informális keretek között jellemző (Eraut, 2000; Leonardi, 2015). Ebben az esetben a szakmai információk, a munkához szorosan köthető információ, tudás megosztása gyakran társul személyes információk kiegészítésével.

A vállalatok többsége régóta tisztában van a megosztott tudás, információ jelentőségével, de a formális megoldásokon ritkán lépnek túl, vagyis nem használják ki az informális megoldásban rejlő lehetőségeket. Egy korábbi kutatás szerint az emberek 73 százaléka akkor osztja meg tudását informálisan, ha annak célja van. 46 százalék nem osztja meg tudását, mert tart attól, hogy ellopják az ötletét. A megkérdezettek 64 százaléka szerint a vezetőjüknek fontos a tudásmegosztás, de csak 34 százalék kap ehhez támogatást (Krauthammer, 2012).

Tudomásul kell venni, hogy ahol emberek dolgoznak együtt, ott a személyes kapcsolatok nem csak természetes részét képezik a szervezeti együttmüködésnek, de elengedhetetlenül szükségesek is a teljesítményhez (Bencsik \& Juhász, 2015).

A tudás/információ továbbításának formális kereteit a szervezeti szabályzatok tartalmazzák. Pontosan meghatározott viselkedési minták alapján várják el a munkavégzéshez szükséges tudás, információ rendelkezésre állásának biztosítását. Ezzel szemben az informális tudás/információmegosztásnak nincsenek - a munkahelyi vezetés által elöírt - formális keretei, bárhol, bármilyen módon megtörténhet annak átadása vagy cseréje. A közvetítő csatornák és helyek csak a lehetőségek és a fantázia függvénye. Mivel nincsenek szabályok, így az informális (munkahelyi vezetés által nem szabályozott) módon történő megosztás sokszínüsége érvényesül, melyek közül az egyik a munkahelyi pletyka. Ennek vizsgálata, illetve szervezeti folyamatokra való hatása képezi a kutatás fókuszát. (A cél nem a pletyka szociológiai, társadalmi szerepének, személyekre történő lelki hatásának értelmezése, vizsgálata, hanem a menedzsmenttudományok területén jelentőséggel bíró, a TM-ciklus egyik fontos lépésének - tudásmegosztás - vizsgálata, mely ebben a megközelítésben ez ideig kimaradt a szakmai körök kutatásainak palettájáról.)

A tudásmegosztás, információátadás e formájának (munkahelyi pletyka) hangulata, kimenete, következménye lehet pozitív vagy negatív az érintetteket tekint- ve. Sajnos a legtöbb esetben a pletyka negatív hatása él a köztudatban, holott a pozitív kimenetek kifejezetten hasznos információkat jelenthetnek a vezetőknek és a közösségnek egyaránt (Szvetelszky, 2017). Kutatásunk célja a munkahelyi pletyka (mint informális tudásmegosztás egy lehetséges módja) jelentőségének, előfordulásának és következményeinek feltárása. Ehhez az alábbi kutatási kérdések megválaszolása szükséges: Mennyire elterjedt a mindennapi szervezeti müködés támogatásában vagy akadályaként a pletyka, mikor és hogyan jelenik meg? Foglalkoznak-e vele a munkahelyi vezetők, és gondolnak-e a pletyka pozitív és negatív gazdasági következményeire? A kutatási kérdéseket egy saját modell alapján, kérdőíves lekérdezés segítségével, komplex statisztikai elemzésekkel teszteltük, SPSS program alkalmazásával, 310 fös mintát alapul véve. A pontos és részletes adatokat az elemzési rész tartalmazza. A további fejezetekben az irodalmi áttekintés után a saját modell bemutatása következik, amely kutatásunk logikai alapját képezi. A kutatási módszertan ismertetését az annak lefolytatása során szerzett tapasztalatok és az eredmények kiértékelése követi. Az eredményeket korábbi kutatásokkal vetjük össze a diszkusszió során és összegezzük következtetéseinket.

\section{Irodalmi áttekintés}

\section{Tudásmenedzsment - tudásmegosztás, átadás}

Mind elméletben, mind a szervezeti gyakorlatban a TM-működtetés leginkább kritikus lépése a megfelelő tudás megszerzése és annak megosztása a szervezetben. Számtalan eszköz áll rendelkezésre mindennek megvalósításához, azonban a szervezeti kultúra, mint előfeltétel befolyásolja az eszközök közüli választást és azok cél szerinti alkalmazását. A tanulószervezeti jellemzők alapfeltételt jelentenek a tudásmenedzsment-rendszerek építése és müködtetése szempontjából. Ezek a jellemzők elsősorban a bizalomra épülő viselkedés, valamint a folyamatos tanulási hajlandóság, a nyitottság, a teammunka, a szervezeti és egyéni célok egyeztetése jellemez. Ezen szervezeti kultúra keretei között sokkal hatékonyabban érvényesül a tudásmegosztás, és a formális megoldások mellett az informális eszközök is fontos szerepet játszanak, sőt gyakran gyorsabb, hatékonyabb eszközök a cél elérésében (Yakel, 2000; Probst, Raub, \& Romhardt 2006; Bencsik, 2015). A tanulmánynak nem célja a tudásmenedzsment-rendszerek és a tudásmegosztás lehetséges megoldásainak tárgyalása, csupán a téma elhelyezése érdekében vázoljuk a legfontosabb tudnivalókat.

A tudásmenedzsment-rendszerek alapvetően támogatják azokat a folyamatokat, melyeken keresztül a tudás (tacit és explicit) átadásra kerül az egyének vagy munkahelyi csoportok között. Ezek a rendszerek tudástárolásra is alkalmas megoldások (Nunes, Annansingh, \& Eaglestone, 2006).

A lessons learned, (a szakmában ezen a néven ismert megoldás, a múlt hibáiból történő tanulást jelenti) szakértői rendszerek, share-point, intranet stb. elsősorban az explicit tudás megosztását teszik lehetővé, a tacit tudás átadását leginkább támogató megoldásként szervezeti 
keretek között a gyakorlati közösségek (communities of practice), a teammunka, illetve a mentori rendszer kerülnek említésre (Azudin et al., 2009; Yi, 2015).

Míg a formális tudásmegosztást támogató megoldások (vállalati, szervezeti szabályzatok, IT-rendszerek, dokumentációk) gyakori vizsgálati témát adnak a kutatók számára, háttérbe szorul az informális tudásmegosztás (spontán, szabályok nélkül) kérdésköre. Az informális tudásmegosztás nagy jelentőségủ a szervezetek számára és összefügg az informális kommunikáció és informális hálózatok kialakulásával. Ez utóbbiak segíthetik vagy akadályozhatják a sikeres müködést, ezért a menedzsment számára nem elhanyagolható a velük kapcsolatos lehetöségek tisztázása (Awazu, 2004; Werr \& Sjernberg, 2003; Bresnen, 2003; Yi, 2015). Építve a tudásszerzés és -megosztás problematikus mivoltára a szervezeti müködésben, kutatásunk középpontjába az informális tudásmegosztás egy hétköznapi és mindenki által gyakorolt formája került, nevezetesen a pletyka, különös tekintettel annak szervezeten belüli érvényesülésére.

\section{Az informális tudásmegosztás}

A szervezetek számára egyre fontosabbá válik a tudásunk rejtett formája, a fentiekben már említett tacit tudás, amely komoly szervezeti vagyon. Bár a hagyományos és mindenki által jól ismert Nonaka (1994) modellje kiválóan reprezentálja a tudásátadás folyamatát, a megvalósítása a mindennapok gyakorlatában közel sem ilyen egyszerü.

Korábbi kutatások szerint az informális tudásmegosztás, az informális kommunikáció, valamint az informális hálózatok koncepciója között átfedés fedezhető fel (Taminiau, Smit \& Lange, 2007). McEvily és Reagans (2003) azt állítja, hogy a munkatársak közötti üzleti kapcsolatok és kialakult baráti kapcsolatok segítik a tudásmegosztás lehetőségeinek szélesítését. Krogh, Nonaka \& Nishiguchi (2000) szerint a bizalomra épülő, nyitott szervezeti kultúra előfeltétele a tudásmegosztásnak. Sturdy, Schwarz \& Spicer (2006) hangsúlyozzák az informális környezet megteremtésének jelentőségét. Szerintük az informális találkozások támogatják a nyitott kultúrát, ezzel együtt a kiegyensúlyozott tudáscserét nem csak a munkatársak között, de a tanácsadók és ügyfelek között is.

Swap és munkatársai (2001) szerint a szervezetek közötti tudásátadás is gyakran a munkatársak tudattalan fecsegése során történik meg, vagyis informális interakciók során. Ez azt is jelenti, hogy a tudás átadásának ugyan nincs kifejezett célja, mégis megtörténik. Truran (1998) állítja, hogy a szervezeten belüli kommunikáció módja is nagyon megváltozott, a szervezeteken belüli tudásmegosztás több mint fele informális módon történik (ad hoc channels). Krogh et al. (2000) szerint is a tudásmegosztás nagyobbik hányada informális módon valósul meg, hacsak nincs a szervezetnek szigorú intézményesített kommunikációs rendszere.

A tudásmegosztásnak komoly jelentősége van az innovatív megoldások kialakításában is. Werr és Sjernberg (2003) kutatásaikban azt tapasztalták, hogy a kreatív gondolatok leginkább informális keretek között születnek. Az egyének összegyült tapasztalatai, melyek általában tacit jellegủ tudást jelentenek, a sztorik elmesélése következtében kerülnek megosztásra (story telling) (Denning, 2004). Bár ez a tudás tacit, az átadás során részben explicitté válik. A tapasztalati tudás ily módon szervezeti szintre történő kiterjesztése az informális terek adta lehetőségek kihasználásának eredménye, ami azt igazolja, hogy szükség van az informális tudásmegosztásra (Werr \& Sjernberg, 2003).

Taminiau et al. (2007) az informális tudásmegosztást úgy definiálja, mint a tudásmegosztás minden olyan formája, amely az intézményesített tudásátadás formáit kíséri.

Ives és munkatársai (2003) szerint a tudásmegosztás, mint emberi viselkedés vizsgálandó az emberi teljesítmény függvényében. Az emberi teljesítmény komplex tevékenység eredménye, melyet több faktor befolyásol, pl. üzleti környezet, szervezeti jellemzők és egyéni jellemzők. A szervezeti jellemzők magukban foglalják a struktúrát, szerepeket, folyamatokat, fizikai környezetet, kultúrát (Wabwezi, 2011; Baksa \& Báder, 2020). Kutatásunk szempontjából az alábbi szervezeti jellemzőknek van jelentősége, melyeket a munkahelyi pletyka, mint informális tudásátadás hatása befolyásol (pro vagy kontra).

- tudásmegosztás: információ/tudás kölcsönös átadásának módja és mélysége,

- szervezeti kommunikáció: kommunikációs csatornák használatának gyakorisága és a kommunikáció minősége,

- dolgozói javadalmazás: a munka ellenértékeként kapott pénzbeli és nem pénzbeli juttatásokkal való elégedettség,

- karrier: szervezeti hierarchiában történő elmozdulás,

- szervezeti kultúra: munkatársi és vezetői viselkedés, normák, értékek,

- csapatmunka: személyes konfliktusoktól mentes együttmüködés,

- hatékonyság: az adott feladattal töltött idő függvényében történő teljesítmény.

\section{A munkahelyi pletyka}

A pletyka annak ellenére, hogy mindenki életében jelen van valamilyen formában, ritkán kerül a kutatások fókuszába. Ha mégis, elsősorban a viselkedéskutatók vagy kommunikációval foglalkozó szakemberek, pszichológusok és szociológusok preferált területe.

Az értelmező szótár szerint a pletyka ,valamely személyes vagy magánügyet, illetve koholt, elferdített dolgot, ügyet bizalmasan vagy alattomosan tárgyaló, kiteregetö, indiszkrét, felelőtlen vagy rosszakaratú hír, amely valakit erkölcsi vagy társadalmi tekintetben rendszeresen gyanúba vagy rossz hírbe hoz" (Bárczi \& Országh 2016).

A pletyka során másokról beszélünk, értékelő módon, a hátuk mögött. (De az értékelés nem feltétlenül és nem minden esetben negatív.) A mindennapi életben leginkább pejoratív értelemben beszélünk róla, de a társadalomtudományi kutatások szerint a pletykának szerepe van a társas rend, az együttműködés biztosításában, a társadalmi 
és szervezeti normák fenntartásában (Feinberg \& Willer, 2010; Parker, 2014; Szvetelszky, 2017).

Jelen kutatás nem kívánja sem pszichológiai, sem szociológiai szempontból boncolgatni a pletyka jellemzőit, társadalmi hatásait. Kifejezetten menedzsmentszempontból vizsgáljuk a szervezeten belüli előfordulását, szervezeti jellemzőkre gyakorolt hatását, a ráfordított vezetői figyelmet.

A pletyka munkahelyen belüli szerepének vizsgálata során a kutatásokban elsősorban a csoportos viselkedésen keresztül ítélik meg hatásait (Sommerfeld, Krambeck, Semmann \& Milinski, 2007). Több esetben az irigység, a reziliencia és a normaszegés kerül a kutatások fókuszába, hanyagolva a következmények gazdasági hatásait (Seppälä, 2016; Kuo, Chang, Quinton, Lu \& Lee, 2015; Ellwardta et al., 2012). E vizsgálatok kapcsán több esetben a bizalom, mint szükséges előfeltétel szerepel, rávilágítva a pletyka és bizalom kölcsönös kapcsolatára. Egyrészt a kapcsolat szükséges, mert a pletyka indításának vagy továbbadásának feltétele, hogy megbízzunk a fogadó félben, remélve, hogy az információ nem kerül tovább, vagy ismerve a befogadó felet, a cél épp az, hogy biztosan továbbadja. Másrészt a bizalom könnyen megsérül, ha kiderül, hogy valaki a közösséget pletykák útján próbálja bomlasztani. Ez esetben a munkatársak bizalmatlanná válnak, és a pletyka ellenkező hatást vált ki a közösségben. Nem áll meg, legfeljebb irányt vált, és hatása nagy valószínűséggel negatív előjelü lesz (Tassiello, Lombardi \& Costabile, 2018).

Ellwardt, Steglich és Wittek (2012) tanulmányukban szintén a bizalom és a pletyka összefüggését vizsgálták. Megállapításaik szerint a negatív tartalmú információk terjedése a menedzserekről a bizalom mértékétől függ. Ennek szellemében a negatív tartalmú pletyka a menedzserekről növekvő tendenciát mutat, ha a bizalom alacsony fokú a munkatársak részéről. A hatás tovább növekszik, ha a munkatársak között gyakori és bizalomra épülö kapcsolat van. Kutatásaik eredményét illusztrálja az 1. ábra.

1. ábra

\section{A szervezeti bizalom és a pletyka összefüggései}

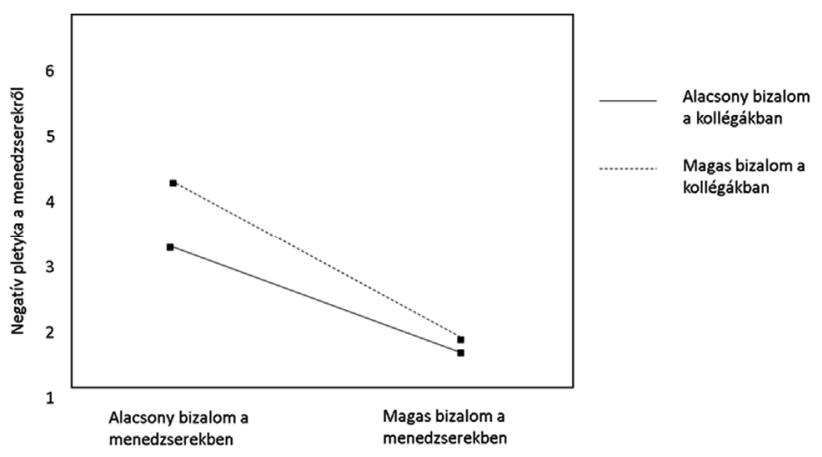

Forrás: Ellwardt, Wittek \& Wielers (2012) alapján saját szerkesztés

A közösségeken belüli pletyka, ami a hírnév megsértéséről szól, többször kerül a kutatások fókuszába. Ennek kapcsán a szociális és önző viselkedés vált központi kérdéssé, ki hogyan reagál a pletyka formájában történő sértések hírére, és az interakcióban részt vevő partnerek között milyen kapcsolat alakul ki a személyiségjegyek függvényében (Ellwardt, Wittek \& Wielers, 2012).

Ellwardt, Labianca és Wittek (2012) a pletyka pozitív és negatív hatását egyaránt vizsgálták. A negatív tartalmú információ általában célzott, pontosan lehet tudni, kire irányul. A pozitív tartalmú pletyka ezzel szemben sokkal lassabban terjed a hálózatokban.

Ahogy a fentiekből is érezhető, a pletyka megítélése inkább negatív, mint pozitív. Feltehető a kérdés, hogy akkor miért is pletykálunk valójában? A pletyka nem létezne, ha nem lenne rá szükség. Információt szolgáltat az emberi környezetről. Aki hallja a pletykát nem biztos, hogy továbbadja, de ha mégis, akkor akarva-akaratlanul változtat rajta. A szervezetek számára nagyon fontos tudás- vagy információmegosztás és a munkahelyi pletyka szorosan összefonódik, ezért annak értékelése vezetői feladat (Bencsik \& Juhász, 2018).

A munkahelyi pletyka létezését senki sem kérdőjelezi meg. Az emberi kommunikációt tekintve a beszélgetések 90\%-a pletykának minősül. Ez azt jelenti, hogy nagy valószínüséggel mi magunk is kezdeményezünk vagy hallgatunk meg pletykákat. Fontos tudni azonban, hogy nemcsak a folyosói suttogások számítanak pletykának, hanem a munkahelyi levelezések közel 15\%-a is, ahol a negatív pletykák 2,7 alkalommal többször fordulnak elö, mint a pozitívak (Szvetelszky, 2017).

Munkahelyi környezetben óriási jelentősége van a megfelelő kommunikációs csatornák kiépítésének és müködtetésének, amelyek a munkavégzés és a munkahelyi teljesítmény befolyásolásán túl a munkatársak közérzetére, viselkedésére is hatást gyakorol (Feinberg, Willer \& Schultz 2014a; 2014b). Ahol nem megfelelő a belső hivatalos kommunikáció, ott sokkal inkább felértékelődik az informális csatornák szerepe, amelyek betöltik az ürt, amit a hivatalos utak hiánya okoz. Ezen informális csatornákon gyorsabban terjednek a hírek és természetesen a pletykák (Georganta, Panagopoulou \& Montgomery, 2014). Az egyik leggyakoribb eset, amikor pletykák indulnak útra a szervezetben, a nagy változások idejére tehetők. Az elégtelen vagy elhallgatott információk, a kiszivárogtatott hírekkel kombinálva garantált pletyka áradatot, találgatásokat, téves híreket indítanak. Mivel a változásokkal járó bizonytalanság információéhséget okoz, a vezetők feladata, hogy a keletkezett ürt kitöltsék valós tényekkel, mielőtt a munkatársak által generált találgatások tényszerü hírré nem válnak. Ha idejében cselekszik a vezetö, és osztja meg beosztottaival az információkat - még akkor is, ha az kellemetlen -, kevésbé válnak a híresztelések áldozataivá munkatársai. Ilyen esetekben nemcsak a gyorsaság számít, hanem a rendszeresség, következetesség és hitelesség is. Ha a vezetô rendszeres tájékoztatást ad, a pletyka keletkezése és negatív hatása is a minimumra csökken (Volek \& Novotna, 2016; Lorincova, 2018).

A pletyka hatása nemcsak munkahelyi problémákkal összefüggésben érezhető a szervezeti müködés során, hanem a személyes kapcsolatok következményeként is befolyást gyakorolhat a teljesítményre. A vezetői nyílt kommunikáció, viselkedési minta, minimálisra csökkentheti a 
pletyka keletkezését, terjedését (Wilkie, 2019; Rudnickia et al., 2019). A kérdés azonban, hogy valóban meg kell-e akadályozni a pletykát? Ahogy a fentiekben már szó esett róla, a pletyka pozitív következményekkel is bírhat, ami a munkahelyi feltételek között is igaz. Ösztönözheti az együttmüködést, felhívhatja a figyelmet a kiváló munkatársakra, és kiküszöbölheti a munkahelyi bántalmazást - állapították meg a Stanford Egyetem kutatásai (Feinberg et al, 2014a).

\section{Az informális tudásmegosztás logikája}

Ahogy az előző fejezetekben leírtuk, a tudásmegosztás szervezeti gyakorlata a hivatalos formális csatornák igénybevétele mellett nagyrészt informális csatornákon történik. Ezek a csatornák közvetíthetnek valós és nem valós tartalmú információkat. Mind a két esetben lehetőség van arra, hogy a továbbításban érintett felek döntsenek arról, hogy a tudást vagy információt továbbadják a szervezeten belül munkatársaiknak vagy sem.

Az informális csatornák utolsó láncszemét követően (lásd elméleti modell) a továbbított információ vagy tudás szervezeti folyamatokra, szervezeti jellemzőkre gyakorolt hatása értékelhető. Igaz, e hatások kézzelfoghatósága, számszerüsítése komoly kihívás, de létezésük nem kérdőjelezhető meg. Egyebek mellett a pletykálkodással töltött idő, (legyen az pozitív vagy negatív kicsengésü információ) a megosztott vagy elvont figyelem, a kialakuló kellemetlen légkör, a bizalmatlanság, a feszültség a munkatársak között vagy vezetőkkel szemben, a gyakoribb hibázás lehetősége, a minőségi problémák mind következményekkel járnak. Ha tetten érhetők a pletyka következményei, kiszámíthatóvá válnak a gazdasági következmények is.

Gondolatmenetünket a 2. ábra szemlélteti. A modell a fentiekben leírt kapcsolatrendszert ábrázolja, amely alapja a további statisztikai elemzésünknek.

\section{2. ábra}

\section{A vizsgálati modell}

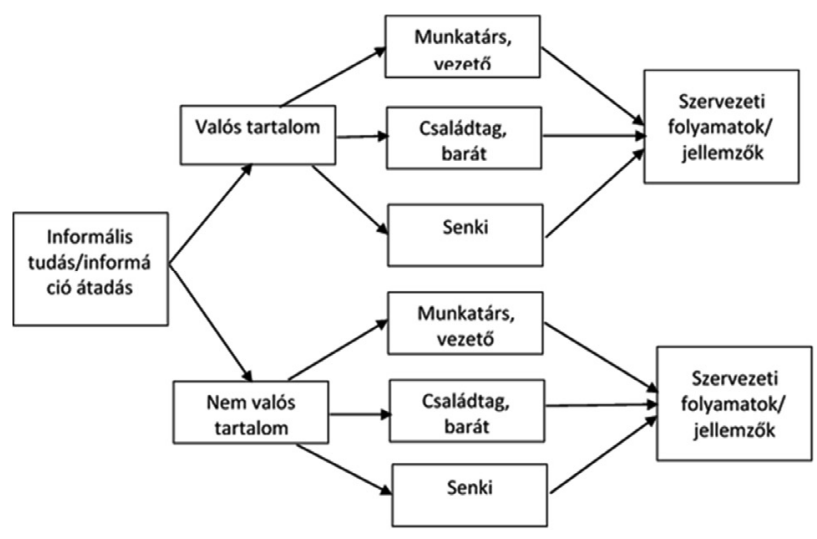

Forrás: saját szerkesztés

\section{Gyakorlati kutatás}

\section{Minta és módszerek}

2018-ban kvantitatív kutatás keretében mértük fel, hogy miképp befolyásolja az informális tudásmegosztás (azon belül a munkahelyi pletyka) a szervezetek müködését, és ezeknek a folyamatoknak milyen hatásuk van a szervezetre, elsősorban müködésük kimenetét érintően. A kutatás során magyarázó jellegű vizsgálatot végeztünk az ok-okozati összefüggések azonosítására.

A kérdőíveket a válaszadók önkéntesen, névtelenül, interneten keresztül töltötték ki. A vizsgálat során egyéneket kérdeztünk meg az informális tudásmegosztási szokásaikról saját szervezeteiken belül. A kérdőív alapvetően metrikus és nominális változókra épült, a kérdések zárt jellegüek voltak. Szerkezetét az 1. táblázat foglalja össze.

1. táblázat

\section{A kérdőív szerkezete}

\begin{tabular}{|c|c|c|c|}
\hline 1. kérdéskör & 2. kérdéskör & 3. kérdéskör & 4. kérdéskör \\
\hline $\begin{array}{l}\text { Szervezeti } \\
\text { specifikáció }\end{array}$ & $\begin{array}{l}\text { A munkavég- } \\
\text { zést jellemző } \\
\text { informális és } \\
\text { formális tudás } \\
\text { és információ } \\
\text { megosztás }\end{array}$ & $\begin{array}{l}\text { A hiteles és } \\
\text { nem hiteles } \\
\text { információk } \\
\text { és tudás to- } \\
\text { vábbítása }\end{array}$ & $\begin{array}{l}\text { A pletykál- } \\
\text { kodás }\end{array}$ \\
\hline $\begin{array}{l}\text { Szervezet el- } \\
\text { helyezkedése, } \\
\text { mérete, ipará- } \\
\text { gi működése. } \\
\text { A kitöltő } \\
\text { neme, kora, } \\
\text { iskolai vég- } \\
\text { zettsége, be- } \\
\text { osztása } \\
\text { Tulajdon vi- } \\
\text { szonyai. } \\
\text { A tudás fon- } \\
\text { tosságának } \\
\text { megítélése. }\end{array}$ & $\begin{array}{l}\text { Formális mó- } \\
\text { dok. } \\
\text { Informális } \\
\text { módok. } \\
\text { Megosztást } \\
\text { célzó szemé- } \\
\text { lyek. } \\
\text { Megosztandó } \\
\text { információk } \\
\text { tartalma. }\end{array}$ & $\begin{array}{l}\text { A szakmai és } \\
\text { nem szakmai } \\
\text { hiteles és } \\
\text { nem hiteles } \\
\text { információk } \\
\text { és a tudás/ } \\
\text { információ } \\
\text { továbbításá- } \\
\text { nak esetei }\end{array}$ & $\begin{array}{l}\text { A pletyka } \\
\text { definíciója. } \\
\text { A pletyka } \\
\text { tartalma. } \\
\text { Szakmai és } \\
\text { nem szakmai } \\
\text { pletyka. } \\
\text { A pletyka } \\
\text { hatásai. } \\
\text { A pletyka } \\
\text { megítélése. }\end{array}$ \\
\hline
\end{tabular}

Forrás: saját szerkesztés

A mintagyüjtési módszer hólabdaeljárással történt, az egyszerü kivitelezhetősége, és a mintagyüjtés korlátai miatt. A minta nem reprezentatív. Magyarországi válaszadókat céloztunk meg, akik az interneten keresztül tudták anonim és önkéntes formában kitölteni a kérdöívet. Próbalekérdezés is történt tíz fö bevonásával, és miután a kérdésekkel nem volt értelmezhetőségi problémájuk a válaszadóknak, valamennyi kérdést meghagyták a szerzők. A kutatás során 310 megkérdezett töltötte ki a kérdöívet és valamennyi válaszadói kitöltés használható volt, nem voltak hiányzó értékek a kiértékelés során. Az elemzéshez egy- és többváltozós statisztikai eljárásokat alkalmaztunk: gyakoriságot, átlagvizsgálatokat, ANOVA-t, faktoranalízist és lineáris regressziót.

A kutatás a fentiekben bemutatott logikai modellnek megfelelően első lépésben azt elemzi, hogy az információkat vagy tudást informális módon miképpen osztják meg a vizsgálatban résztvevők a munkavégzés során. Az eredményeket tovább vizsgáltuk abból a szempontból, hogy valóságtartalmuk függvényében (azaz igazak, vagy sem), kinek adják tovább? Végezetül pedig, hogy a pletykának milyen hatása van a szervezeti jellemzőkre, folyamatokra? 
Ahhoz, hogy az adott minta esetében az informális tudásmegosztási hajlandóságot vizsgálni lehessen, egy érintettségi indexet (Informindex) (Obadovics, 2006) képeztünk. Az index létrehozása során több, különböző mérési szintü alapmutató összevonása történt egyetlen változóba. Ezt a mutatót a következő (a kérdöívben szereplö) kérdésekből álló részindexekből alkottuk meg: Mennyire jellemzi a munkavégzés során az információmegosztás (beszélgetés) alábbi módja: büfében, ebéd közben, kiküldetés során, közös közlekedés során, közösségi felületeken, dohányzás közben, pihenő időben, öltözőben, munkavégzés közben. Ezek a változók ötfokozatú skálákra épültek, ahol az egyáltalán nem jellemző az egyest, míg a teljesen jellemző az ötöst jelentette. A részindexek képzése során az 1-es és 2-es skálaérték átkódolása 1-est, a 3-as skálaérték 2-est, míg a 4-es és 5-ös skálaérték 3 -as értéket ért. Az indexértéket a 9 részindex összege adta, aminek a maximális értéke 27 lehetett, ez jelentette a legnagyobb mértékủ informális tudásátadási hajlandóságot. Az Informindex érintettsége 8 esetben volt 9-es értékü, (legalacsonyabb), míg 42 esetben 27-es értékü (legmagasabb). Az index megoszlását a 2. táblázat mutatja.

2. táblázat

Az informális tudástranszfer érintettségi indexének megoszlása

\begin{tabular}{|c|c|c|}
\hline Indexértékek & $\begin{array}{c}\text { Válaszadók száma } \\
(\mathbf{N})\end{array}$ & $\begin{array}{c}\text { Indexértékek aránya } \\
(\%)\end{array}$ \\
\hline 9,00 & 8 & 2,6 \\
\hline 10,00 & 7 & 2,3 \\
\hline 11,00 & 11 & 3,5 \\
\hline 12,00 & 21 & 6,8 \\
\hline 13,00 & 12 & 3,9 \\
\hline 14,00 & 17 & 5,5 \\
\hline 15,00 & 13 & 4,2 \\
\hline 16,00 & 22 & 7,1 \\
\hline 17,00 & 12 & 3,9 \\
\hline 18,00 & 26 & 8,4 \\
\hline 19,00 & 21 & 6,8 \\
\hline 20,00 & 18 & 5,8 \\
\hline 21,00 & 10 & 3,2 \\
\hline 22,00 & 12 & 3,9 \\
\hline 23,00 & 14 & 4,5 \\
\hline 24,00 & 12 & 3,9 \\
\hline 25,00 & 22 & 7,1 \\
\hline 26,00 & 10 & 3,2 \\
\hline 27,00 & 42 & 13,5 \\
\hline Total & 310 & 100,0 \\
\hline & & \\
\hline
\end{tabular}

Forrás: saját szerkesztés

A 9-töl a 27-ig tartományt ezután érintettségi fokozatokba soroltuk az átlag és a szórás segítségével. Az átlagot felhasználva 0,5-ös szórásegységhez rendeltük a kategóriahatárokat (Obadovics, 2006), miután az eloszlás közelített a normál eloszláshoz. A három kategória így a gyengén, közepesen és erősen érintett elnevezést kapták. Az Informindex alapján a 3. táblázatban látható módon alakultak a kategóriák.
3. táblázat

Az informális tudástranszfer érintettségi indexének kategóriái

\begin{tabular}{|c|c|c|}
\hline Kategóriák & $\mathbf{N}$ & $\%$ \\
\hline Gyenge & 123 & 39,7 \\
\hline Közepes & 75 & 24,2 \\
\hline Erős & 112 & 36,1 \\
\hline Összes & 310 & 100,0 \\
\hline
\end{tabular}

Forrás: saját szerkesztés

A három kategória alapján redukáltuk a mintát, és az erős és a közepes kategóriába tartozó válaszadókat tartottuk meg a vizsgálatban, azaz olyan megkérdezetteket, akikre jellemzően legalább közepesen igaz, hogy informálisan osztanak meg tudást vagy információt a munkahelyükön. Így a vizsgált minta 187 fö lett.

A minta redukálását követően a minta egyváltozós specifikálását végeztük el. A legjellemzőbb információkat a 4. táblázat mutatja be.

4. táblázat

\section{A minta specifikációja}

\begin{tabular}{|l|l|l|}
\hline \multicolumn{1}{|c|}{ Tulajdonságok } & \multicolumn{1}{|c|}{ Szempontok } & Arányok (\%) \\
\hline \multirow{4}{*}{ Vállalati méret } & Mikro & 16,60 \\
\cline { 2 - 3 } & Kis & 16,00 \\
\cline { 2 - 3 } & Közepes & 33,70 \\
\cline { 2 - 3 } Tulajdonviszonyok & Nagy & 33,70 \\
\hline \multirow{4}{*}{$\begin{array}{l}\text { Kitöltő legmagasabb } \\
\text { iskolai végzettsége }\end{array}$} & Kizárólag hazai & 47,60 \\
\cline { 2 - 3 } & Vegyes & 16,60 \\
\cline { 2 - 3 } & Kizárólag külföldi & 35,80 \\
\cline { 2 - 3 } & Középfokú & 4,30 \\
\cline { 2 - 3 } & Felsőfokú & 64,10 \\
\hline \multirow{4}{*}{$\begin{array}{c}\text { Ön beosztása a } \\
\text { cégnél? }\end{array}$} & Beosztott & 31,60 \\
\cline { 2 - 3 } & Alapszintü vezető & 17,60 \\
\cline { 2 - 3 } & Középszintü vezető & 11,80 \\
\cline { 2 - 3 } & Felső szintü vezetö & 4,80 \\
\cline { 2 - 3 } & Tulajdonos & 10,20 \\
\hline
\end{tabular}

Forrás: saját szerkesztés

93 nő és 94 férfi töltötte ki a kérdőívet, akik átlagos életkora 34 év volt.

\section{Hipotézis}

Az informális tudásmegosztás (munkahelyi pletyka) befolyásolja a szervezet jellemző folyamatait, a negatív tartalmú pletyka különösen a szervezeti hatékonyságot.

\section{A kutatás eredményei}

A kutatás során megkérdeztük, hogy informális módon az információkat milyen gyakorisággal osztják meg a ku- 
tatásban résztvevők. Egy ötfokozatú skálán kellett erre a kérdésre válaszolniuk. Az egyes a soha, míg az ötös érték a mindig meghatározást jelentette. A személyes információk továbbadását illetően viszonylagos zárkózottságot mutatott a minta, mert az átlag csak 2,86 lett, vagyis a megkérdezettek közepesen gyakran mennek bele olyan informális beszélgetésekbe a munkahelyükön, ami személyes információkról szól, és nem a munkáról.

Megvizsgáltuk, hogy a személyes tartalmú információk informális módon történő átadási hajlandóságát befolyásolják-e vállalati, esetleg egyéni jellemzők. Több szempontos varianciaelemzéssel elemeztük, hogy a szervezeti specifikumok és az egyéni sajátosságok milyen befolyással bírnak. A szervezeti jellemzők, mint független kategorikus változók a következők voltak: a méret, a tulajdonviszony, betöltött pozíció. Az első kettő változó esetében a 4. táblázatban bemutatott kategóriákat használtuk fel. A pozíció esetében három jellemző kategóriára redukáltuk a változót (beosztott, vezetö, tulajdonos). Az egyéni jellemzőket tekintve az iskolai végzettséget a 4. táblázatban szereplő csoportbeosztással vizsgáltuk, a „nem” esetében értelemszerüen a nőket és a férfiakat elemeztük. Az életkor metrikus változót kategorikussá alakítottuk 10 évenkénti beosztással. Mint ahogyan az 5. táblázat is mutatja, sem a szervezeti, sem az egyéni jellemzőkre épülő modellek esetében nem volt igazolható, hogy a tudásmegosztási, információátadási hajlandóságra ezek a tényezők és azok interakciói szignifikáns hatással lennének.

Az 5. táblázat alapján külön vizsgáltuk a szervezeti tényezők és a személyes jellemzők hatását az információk informális módon történő megosztására vonatkozóan. Mindkét esetben igazolható volt, hogy a két modell nem volt szignifikáns, és mint a táblázatban látható, a tényezők és azok interakciói (kereszthatásai) nincsenek hatással az információ továbbítására.

A táblázatban szereplő parciális $\eta^{2}$ alapján, - amelyek a magyarázott hányadot mutatják - látható, hogy ha bizo- nyítható lenne a szignifikáns befolyás, az információmegosztás szórásának magyarázatában csak kis részt vállalnának a szervezeti és a személyes tényezők. Ez az eredmény azt igazolja, hogy a mintában a szervezeti és a személyes tényezők nem befolyásolják az információk informális módon történő átadását. Ez az eredmény ellentmond a témában született gender kutatásoknak (Szvetelszky, 2010). A különbség visszavezethető esetleg a mintagyüjtés korlátaira, így az eredmény a vizsgált mintára igaz.

Felvetődött a kutatás során az a kérdés, hogy a megosztott információk esetében figyelembe veszik-e azt, hogy az információnak van-e valóságtartalma vagy sem. A valóságtartalom alapján történő megosztásra szintén egy ötfokozatú skálát használtunk, ahol az egyes a soha megfelelője volt, míg az ötös jelezte, hogy mindig átadnak ilyen információkat. Az eredmények azt mutatják, hogy nem nagyon gyakori a hamis információk megosztása (átlag: 1,87), míg a valós tartalmú információk megosztása közepesen gyakran fordul elő (átlag: 2,79). Érdekesség, hogy a megkérdezettek 5 százaléka ad tovább rendszeresen hamis tartalmú információkat, míg 10 százalékuk csak a valós tartalmú információkat osztja meg. Az informális tudás vagy információmegosztás és a nem valós információk továbbítása között erős pozitív korrelációt azonosítottunk (r: ,504 szign.: ,000 p<0,01), és hasonlóan erös pozitivitás volt igazolható a valós tartalommal bíró információk esetében (r: ,673 szign.: ,000 p<0,01). Elemeztük ANOVA vizsgálattal, hogy van-e akár szervezeti, akár egyéni tényező, amely befolyásolja, hogy milyen tartalmú információt adnak tovább a megkérdezettek. A hamis információ esetében azt találtuk, hogy míg a tulajdonviszony és a pozíció nem, addig a vállalati méret befolyásolhatja ezt szignifikáns módon (F: 5,748 df: 3 szign.: ,001 p<0,05). Azaz, amíg a kis cégeknél közepesen gyakori (átlag: 2,67), hogy nem valós információt továbbítanak a munkatársak, addig ez a jelenség viszonylag elenyésző gyakorisággal fordul elö a nagyvállalatoknál (átlag: 1,65).

Az átadási hajlandóságot befolyásoló egyéni és szervezeti tényezők

5. táblázat

\begin{tabular}{|c|c|c|c|c|c|c|c|}
\hline \multicolumn{4}{|c|}{ Szervezeti tényezők } & \multicolumn{4}{|c|}{ Egyéni tényezők } \\
\hline & $\mathrm{F}$ & Szign. & Parciális $\eta^{2}$ & & $\mathrm{~F}$ & Szign. & Parciális $\eta^{2}$ \\
\hline Modell & 1,146 & ,299 &, 151 & Modell & 1,318 &, 166 &, 150 \\
\hline Beosztás &, 423 & ,656 &, 005 & Végzettség & 1,201 &, 303 &, 014 \\
\hline Munkahely mérete & 1,085 & ,357 &, 020 & Életkor &, 803 &, 525 &, 019 \\
\hline Cég tulajdonviszonya &, 195 & 823 & ,002 & Nem &, 062 &, 804 & ,001 \\
\hline Beosztás * Munkahely mérete &, 831 & ,547 &, 030 & Végzettség * Életkor & 1,390 &, 222 &, 048 \\
\hline $\begin{array}{l}\text { Beosztás * Cég tulajdonviszo- } \\
\text { nya }\end{array}$ & 1,809 &, 130 &, 043 & Végzettség * Nem & 1,395 &, 251 &, 017 \\
\hline $\begin{array}{l}\text { Munkahely mérete *Cég tulaj- } \\
\text { donviszonya }\end{array}$ & 1,598 &, 151 & ,056 & Életkor * Nem & 1,346 &, 255 &, 032 \\
\hline $\begin{array}{l}\text { Beosztás * Munkahely mérete } \\
\text { * Cég tulajdonviszonya }\end{array}$ &, 841 &, 433 &, 010 & $\begin{array}{l}\text { Végzettség } * \text { Életkor } \\
* \text { Nem }\end{array}$ & 1,549 & ,204 &, 028 \\
\hline
\end{tabular}

Forrás: saját szerkesztés, $p=0,05$ 
Ennek okát nehéz megmagyarázni, de adódhat a minta összetételéből, jellegéből is. A kérdés az, hogy a sok munkavállalót alkalmazó szervezetnél ugyanolyan valószínűséggel kerül-e napvilágra, hogy kitől származik a hamis információ. Az egyéni jellemzők nem voltak hatással arra, hogy valaki hamis információt oszt meg. Az információk ily módon történő továbbadása azért játszik kiemelt szerepet, mert személyes tapasztalatunk és szakirodalommal is igazolható, hogy a legtöbb problémát, gazdasági hátrányt, munkahely elhagyást az ilyen jellegü információk okozzák (Vajda, 2007; Benett, 2014).

Ha továbbadnak információt vagy tudást - legyen az igaz vagy hamis - kérdés, hogy kinek történik a továbbítás. Az információátadással kapcsolatosan több csatornát is felsoroltunk a válaszadóknak, amelyeket egy ötös skálán kellett értékelniük aszerint, hogy mennyire jellemzően kommunikál az adott csatornán, akár igaz vagy hamis magánjellegű információkat. A megosztási csatornák a következők voltak: azonos pozícióban lévő nem barát kolléga, alacsonyabb pozícióban lévő nem barát kolléga, magasabb pozícióban lévő nem barát kolléga, azonos pozícióban lévő barát kolléga, alacsonyabb pozícióban lévő barát kolléga, magasabb pozícióban lévő barát kolléga, közvetlen vezető, tulajdonos, nem munkahelyi barát, nem munkahelyi ismerős, család, senki. Mind a hamis, mind az igaz információk továbbadása során az adott csatornákat faktorokba tömörítettük Varimax-eljárással. Mindkét esetben (valós vagy hamis információ vagy tudás) három faktort lehetett megkülönböztetni, amelyek a faktorsúlyok alapján a 6. táblázatban olvasható elnevezéseket kapták (a táblázat a faktorokat alkotó komponenseket is mutatja a faktorsúlyuk csökkenő sorrendjében).

6. táblázat

\section{A személyes információ megosztása a valóságtartalom alapján}

\begin{tabular}{|c|c|}
\hline $\begin{array}{l}\text { Valós információ } \\
\text { továbbítása }\end{array}$ & $\begin{array}{c}\text { Nem valós információ } \\
\text { továbbítása }\end{array}$ \\
\hline $\begin{array}{l}\text { Nem barát kolléga vagy ma- } \\
\text { gasabb vezető vagy közvetlen } \\
\text { vezetö } \\
\text { Komponensek: Magasabb } \\
\text { pozícióban lévő nem barát } \\
\text { kolléga, Alacsonyabb pozíci- } \\
\text { óban lévő nem barát kolléga, } \\
\text { Azonos pozícióban lévő nem } \\
\text { barát kolléga, Magasabb veze- } \\
\text { tők, Közvetlen vezetők }\end{array}$ & $\begin{array}{l}\text { Nem barát kolléga vagy } \\
\text { közvetlen vezető } \\
\text { Komponensek: Alacsonyabb } \\
\text { pozícióban lévő nem barát } \\
\text { kolléga, Azonos pozícióban } \\
\text { lévő nem barát kolléga, } \\
\text { Magasabb pozícióban lévő } \\
\text { nem barát kolléga, Közvetlen } \\
\text { vezetők }\end{array}$ \\
\hline $\begin{array}{l}\text { Család és nem munkahelyen } \\
\text { dolgozó barát } \\
\text { Komponensek: Család, Nem } \\
\text { munkahelyen dolgozó barát, } \\
\text { Nem munkahelyen dolgozó } \\
\text { ismerős, alacsonyabb pozíció- } \\
\text { ban dolgozó barát }\end{array}$ & $\begin{array}{l}\text { Család és nem munkahelyen } \\
\text { dolgozó barát } \\
\text { Komponensek: Család, Nem } \\
\text { munkahelyen dolgozó barát, } \\
\text { Nem munkahelyen dolgozó } \\
\text { ismerős }\end{array}$ \\
\hline $\begin{array}{l}\text { Senki } \\
\text { Komponensek: Senki }\end{array}$ & $\begin{array}{l}\text { Senki } \\
\text { Komponensek: Senki }\end{array}$ \\
\hline
\end{tabular}

KMO: ,875 Magyarázott hányad: 80,01\% KMO: 911 Magyarázott hányad: 89,03\% Forrás: saját szerkesztés
A további elemzés során a megosztási csatornákból kivettük a családot és a nem munkahelyi barát elnevezésü faktort, mert az adott vizsgálat esetében nem tekinthetők relevánsnak, miután a vizsgálat a vállalaton belüli információmegosztásra fókuszált. Azt láttuk, hogy mind a valós, mind a hamis információk esetében a válaszadók továbbítanak információt, de a nem valós tartalom esetében elöfordul, hogy senkivel sem osztják meg azt. (Feltételezve, hogy az érintettek tudatában vannak az információ, tudás valóságosságának.) A korrelációs elemzések azt igazolták, hogy a nem valós információk átadása esetében erősebb korrelációval lehet számolni a csatornákat tekintve, mint a valós tartalmak esetében (a korrelációerősségeket a 3. ábra mutatja).

A megosztott tudás vagy információ - attól függően, hogy milyen valóságtartalmuk van és kivel osztják meg - hatással lehet a szervezeti jellemzőkre és folyamatokra. Ezzel kapcsolatban értékelniük kellett a megkérdezetteknek, hogy szerintük milyen szervezeti jellemzöket, folyamatokat befolyásol az átadott információ. Szintén egy ötfokozatú skálán kellett ezeket a hatásokat értékelniük, ahol az 1-es érték az erős negatív hatást, míg az 5-ös a pozitív benyomást jelentette. A következők esetében kellett eldönteniük, hogy az információátadás milyen befolyással bír: a szervezeti kultúrára, a csapatmunkára, a dolgozói karrierre, a dolgozói javadalmazásra, a szervezeti bizalomra, az egyéb tudásmegosztási módszerekre, a szervezeten belüli kommunikációra, a dolgozói munkavégzésre, a szervezeti teljesítményre. Az információ valóságtartalma alapján az adott hatásokat szintén Varimax-eljárással faktorokba tömörítettük, amelyeket a 7. táblázat foglal össze (a táblázat a faktorokat alkotó komponenseket is mutatja a faktorsúlyuk csökkenő sorrendjében).

7. táblázat

\section{A személyes információ hatása a szervezetre}

\begin{tabular}{|l|l|}
\hline \multicolumn{1}{|c|}{$\begin{array}{c}\text { Valós információ } \\
\text { továbbítása }\end{array}$} & \multicolumn{1}{|c|}{$\begin{array}{c}\text { Nem valós információ } \\
\text { továbbítása }\end{array}$} \\
\hline $\begin{array}{l}\text { Tudásmegosztás és szervezeti } \\
\text { kommunikáció } \\
\text { Komponensek: Egyéb tudás- } \\
\text { megosztási módszerek, Szer- } \\
\text { vezeten belüli kommunikáció, } \\
\text { Szervezeti bizalom, Szervezeti } \\
\text { teljesítmény }\end{array}$ & $\begin{array}{l}\text { Komponensek: Szervezeti } \\
\text { kultúra }\end{array}$ \\
\hline $\begin{array}{l}\text { Dolgozói javadalmazás és kar- } \\
\text { rier } \\
\text { Komponensek: Dolgozók java- } \\
\text { dalmazása, Dolgozói karrier, } \\
\text { Dolgozói munkavégzés }\end{array}$ & $\begin{array}{l}\text { Csapatmunka és javadalma- } \\
\text { Kás } \\
\text { ka, Dolgonónsek: Csapatmun- } \\
\text { Egyéb tudásmegosztási mód- } \\
\text { szerek }\end{array}$ \\
\hline $\begin{array}{l}\text { Szervezeti kultúra és csapat- } \\
\text { munka } \\
\text { Komponensek: Szervezeti kul- } \\
\text { túra, Csapatmunka }\end{array}$ & $\begin{array}{l}\text { Szervezeten belüli kommuni- } \\
\text { káció és hatékonyság } \\
\text { Komponensek: Szervezeten } \\
\text { belüli kommunikáció, Szer- } \\
\text { vezeti teljesítmény }\end{array}$ \\
\hline
\end{tabular}

KMO: ,863 Magyarázott hányad: 72,49\% KMO: ,898 Magyarázott hányad: 84,812\%

Forrás: saját szerkesztés 


\section{A lineáris regresszió eredményei}

\begin{tabular}{|l|l|c|c|c|c|c|c|}
\hline \multicolumn{3}{|c}{ Paraméterek } & \multicolumn{5}{c}{ Modellösszegzés } \\
koefficiensek
\end{tabular}

Forrás: saját szerkesztés, $p=0,05$

A vizsgálatok azt igazolták, hogy abban az esetben, ha valós tartalmú információt/tudást adunk át informális módon, a nem barát kollégának, vagy közvetlen, illetve magasabb vezetőnek, ez hatással lehet a tudásmegosztásra és szervezeti kultúrára, a dolgozói javadalmazásra és karrierre, illetve a csapatmunkára. A nem barát kollégával, esetleg közvetlen vezetővel megbeszélt nem valós tartalmú információk a szervezeti kommunikációt és teljesítményt, illetve a csapatmunkát és javadalmazást befolyásolják. Ha valaki nem osztja meg az információkat senkivel, akkor csak a nem valós tartalmú információk esetében lehetett a szervezeti kultúrára gyakorolt hatását kimutatni. Az adott kapcsolatok vizsgálatát lineáris regresszióval igazoltuk, amelyek összesítését a 8. táblázat foglalja össze (a táblázat csak a szignifikáns összefüggéseket tartalmazza).

A fentiekre tekintettel az elméleti modell alapján a következő folyamatokat lehet azonosítani. A mintában szereplő munkavállalók megosztanak információt, tudást a szervezeteken belül informális módon (azaz pletykálnak), igaz, nem túl gyakran. Függetlenül attól, hogy ez valós tartalmú, vagy nem, a továbbadás megtörténik. A valós információkat vagy tudást gyakrabban adják tovább. Ezt a továbbadási hajlandóságot nem befolyásolják az egyéni (nem, kor, iskolai végzettség) és vállalati jellemzők (tulajdonosi forma, beosztás).

Az igazságtartalom hatással van arra, hogy az egyének kivel osztják meg az információkat. Jellemzően a szervezeten belül a vezetőkkel és nem barát kollégával beszélik meg a valós és hamis tartalmú személyes információkat.
A vállalaton kívül a közvetlen barátokkal és családtagokkal, ami azért lehet fontos, mert egyfajta támogatást jelenthet a szervezeten kívüli, (gyakran nem pártatlan) személyektől saját érintettségük esetén. Ennek a megosztási csatornának a szervezeti hatását a jelen vizsgálatban nem elemeztük.

Az, hogy kivel beszéli meg az egyén az információkat, befolyással van arra, hogy az információ vagy tudás átadása milyen következményekkel járhat a szervezetre. A valós tartalmúak befolyásolják a tudásmegosztás további módjait, a szervezeti kultúrát, a csapatmunkát, a dolgozói karriert. A hamis információk kihatással vannak a kommunikációra, a csapatmunkára, a javadalmazásra, a szervezeti teljesítményre. Az is elöfordul, hogy valaki nem akar hamis tartalmú információt megosztani senkivel, (nem akar pletykálni) amely erősíti a vállalati kultúrát. A fent leírtakat a 3. ábrán látható modellkapcsolat rendszere illusztrálja.

Az eredmények alapján látható, hogy a hipotézis, miszerint a nem valós tartalmú információk (munkahelyi pletyka) az alapvető szervezeti folyamatokra hatással vannak, negatív módon befolyásolják a csapatmunkát, a javadalmazást, a szervezeti kommunikációt és a hatékonyságot, beigazolódott. A csapatmunka esetében demoralizálja a csapatot és konfliktusokat eredményezhet. A javadalmazást tekintve, mint korábbi kutatások is kimutatták (Thiabaut \& Kelley,1958) az egyéni haszonszerzés céljából, akár még a hamis pletykáktól sem riadunk vissza. A szervezeti kommunikációban gyökeret verhet a bizalmatlan- 
ság, a titkolózás. Ezek a hatások együttesen csökkenthetik a szervezetben dolgozók mind egyéni, mind pedig a csapatmunkára épülő hatékonyságát. Vagyis azokban a tényezőkben okoznak kárt, amelyek a munkatársak közötti együttmüködésre, az egymás iránti lojalitásra épülnek, és ezen keresztül a tudásmegosztásra is hatással vannak. Ennek eredménye kétségtelenül a müködési hatékonyságot, a szervezeti teljesítményt is befolyásolja. Azaz a hosszú idő alatt kiépített pozitív szervezeti tényezőket negatív irányba mozdítják el. Függetlenül attól, hogy az esetek többségében nem pozitívan érinti a pletykálkodás a szervezeti értékeket, mégis minden szinten jelen van a munkahelyeken. Söt, a válaszadók harmada nyilatkozott arról, hogy egyszerre párhuzamosan több pletyka is fut a cégükön belül. 12 százaléka a válaszadóknak érezte eddig bármilyen pozitív hatását, miközben 34 százalék negatívan érintett a pletykálkodásban. Ám ennek ellenére csak 40 százaléka ellenzi erkölcsileg a pletykálkodást, ami valamelyest kontrasztot vetít a fenti eredményekre.

3. ábra

Az informális tudásmegosztás (munkahelyi pletyka) hatása a szervezeti folyamatokra

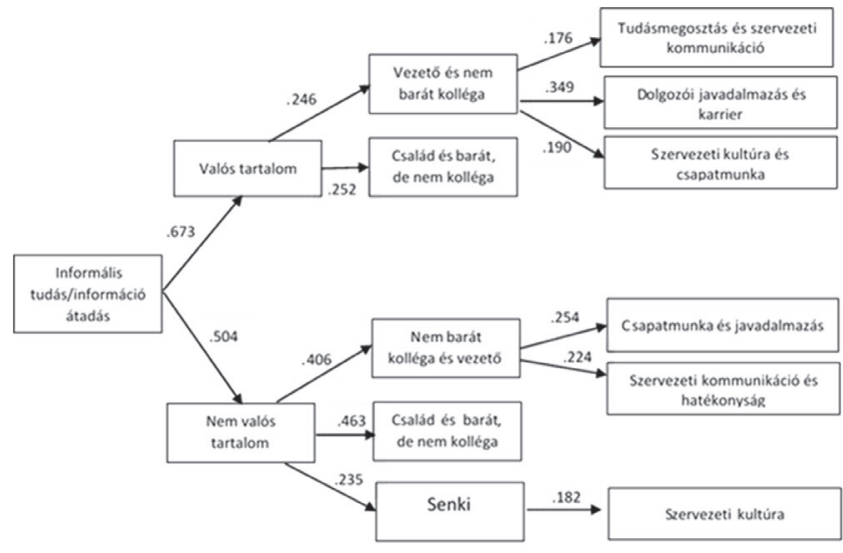

Forrás: saját kutatási eredmények

Az eredmények alapján a hipotézist elfogadottnak tekinthetjük.

\section{Diszkusszió}

Az eredmények szerint igaz, hogy a pletyka kimutatható módon hatással van a szervezeti müködésre, szervezeti jellemzőkre és folyamatokra. A pletyka hatása inkább negatív, mint pozitív irányt mutat. Ennek ellenére a pletykával, mint jelenséggel, és annak következményeivel a vizsgált szervezetek többsége nem foglalkozik.

Elméleti szinten átfedés tapasztalható az informális tudásmegosztás, informális kommunikáció és az informális hálózatok fogalmai között (Taminiau et al., 2007), mely azt jelzi, hogy ezen a területen további tisztázandó kutatási irányok körvonalazódnak. Bár valamennyi esetben a pletyka munkahelyi müködésre gyakorlott hatása felmerül, a jelenség létezésének és hatásának deklarálásán túl nem jutnak a kutatók. A szerzők által végzett kutatás e tekintetben új eredményeket jelent a szakmai érdek- lődők számára. Werr és Sjernberg (2003) az informális tudásmegosztás létjogosultságát támasztják alá kutatásaikban, hangsúlyozva a gyakorlati tapasztalatok szerzésének szükségességét. Ez az igény jelen kutatásban is igazolt. A szakirodalomban az informális tudásmegosztás és informális hálózatok müködése közötti összefüggések bizonyítottságáról lehet olvasni, mely magában hordozza a munkahelyi pletyka létezésének természetességét (Awazu, 2004; Bresnen, 2003). További kutatások is az informális tudásmegosztás létjogosultságát igazolták és ennek a pletyka formájában történő megjelenését a mindennapi vállalati gyakorlatban, melyeket jelen kutatás is alátámaszt. McEvily és Reagans (2003) kutatásaik eredményeként arról írnak, hogy a munkatársak közötti üzleti kapcsolatok, a baráti kapcsolatok szélesebb körben kiszélesítik a tudásmegosztás lehetőségeit, különösen a bizalomra épülő szervezeti kultúra feltételei között. Krogh et al. (2000) véleménye szerint a nyitott szervezeti kultúra elöfeltétele a tudásmegosztásnak, mely megállapítást a későbbiekben további számos kutatás igazolta. Korábbi kutatásainkban mi is hasonló eredményre jutottunk, amit tovább erősít az a tény, hogy a jelenlegi kutatás alapján is kiderült, hogy a bizalom és a pletyka között összefüggés van. Truran (1998) már évtizedekkel ezelőtt állította, hogy a tudás- vagy információtartalom az informális csatornák (ad hoc channels) igénybevételével gyökeres átalakuláson megy keresztül, aminek egyre inkább teret adnak a telefonon és e-maileken keresztül történő kommunikációs lehetőségek. Ezen csatornák a pletyka formáját is magukban hordozzák, melyek egyre inkább intézményesített formában kapnak teret a szervezetekben (Krogh et al., 2000). Ez azt jelenti, hogy az e-pletyka létezése ma már természetes és vállalati keretek közötti hatása is érzékelhető, de ennek jellemzői jelen vizsgálatban nem igazolódtak.

Werr és Sjernberg (2003) tapasztalataik alapján fogalmazták meg azt a tényt, hogy a tudásszerzés egyik legfontosabb forrása a kreatív ötletek felszínre kerülése informális kapcsolatokon keresztül. Rámutatnak, hogy a tapasztalatok megosztása is sokkal gyakrabban az informális csatornákon keresztül történik, mint pl. spontán beszélgetések a hallban vagy ebéd, illetve kávézás közben. Ezek mint sztorik kerülnek megosztásra bizonyos konkrét esetekről. Ezek a tapasztalatok többségében tacit tudást tartalmaznak, amely a kommunikáció során kézzelfoghatóvá (explicitté) válik a kollégák számára. Ez is alátámasztja az informális tudásmegosztás súlyát, mely az egyébként is nehéz tudásmegosztási folyamatot teszi emberközelivé (Werr \& Sjernberg, 2003). Az így történő információ-, illetve tudásmegosztás óhatatlanul a pletyka lehetőségét hordozza magában, amely nem elsősorban a negatív kommunikáció lehetőségét, sokkal inkább a gyors tudásszerzés, tudásmegosztást támogatja. Az utóbbi évek kiemelt kutatási irányát jelenti a tacit tudásmegosztás lehetőségeinek feltárása és gyakorlati jelentőségének igazolása, ami ily módon a munkahelyi pletykát is érinti. Kétségtelen azonban, hogy ma még a szervezetek vezetői nem értékelik megfelelő helyen ennek a természetes emberi magatartásnak a jelentőségét, és sokkal inkább káros szervezeti jellemzőnek ítélik, mint kihasználható lehetőségnek. 
A jelen kutatás eredményei alapján az informális tudásátadás e formájában mindenféle tudás, információ, magánjellegű ismeretek is átadásra kerülnek, éppen ezért több szempontból is érdemes óvatosan kezelni a munkahelyi pletyka kérdését. A vizsgálatok azt is igazolták, hogy ezt a tevékenységet nem befolyásolja igazán, hogy ki, milyen méretü szervezetben dolgozik, illetve, hogy milyen tulajdonosi szerkezettel rendelkezik az adott cég. Miután a vizsgált minta nem volt reprezentatív, ezért ez utóbbi kijelentésünket nem lehet általánosítani. A pletyka a világ minden pontján része a kultúrának, még akkor is, ha ennek megnyilvánulási formája különböző. Tiltani vagy büntetni nem érdemes, mert sokszor az ellenkezőjét éri el a vezetés ezen megszorító szabályok bevezetésével. A cél inkább a pozitív hozadékának feltárása és kihasználása, mely akkor válik valóban láthatóvá, ha sikerül számszerüen is kimutatni a pletyka gazdasági következményeit a szervezetekre.

\section{Következtetések}

A tanulmány egy, a múlt évben végzett kutatás eredményeit mutatta be, amely az informális tudás- és információátadásról szólt. A kutatásban megfogalmazott hipotézist a fenti eredmények alapján a vizsgált mintára elfogadtuk.

A vizsgálat során kiderült, hogy a transzferálás során nemcsak az a fontos az átadó személy számára, hogy milyen jellegü információt közöl, hanem az is, hogy milyen valóságtartalommal bír az átadni szándékozott tudnivaló. A megosztási hajlandóságot nagyban befolyásolja, hogy az információnak milyen a valóságtartalma. Az információk megosztását különösen negatívan befolyásolja, ha a közölnivaló igazságtartalma megkérdőjelezhető. Habár a kutatásban résztvevőknél a formális információ megosztás népszerübb, mint az informális, ám pletykálni gyakran szoktak a munkahelyükön. Még akkor is, ha tudják, hogy nem feltétlenül pozitív hatása van az informális tudás- vagy információmegosztás e formájának a szervezeti működés jellemzőire.

Az eredmények azt támasztották alá, hogy a szervezet szoft elemeiben tud igazán kárt okozni a pletyka, azokban a tényezőkben, amelyek kiépítése és korrigálása sok időbe telik, és amelyek lerombolása veszteséget okoz a cégeknek. Az emberek annak ellenére pletykálnak, hogy tudják, nem feltétlenül pozitív hozadéka van ennek a tevékenységnek sem a szervezetre, sem saját magukra nézve. Károsnak vélt mivolta ellenére a kutatásban résztvevők többsége erkölcsileg nem ítéli el a pletykát, és talán ennek is köszönhető, hogy a részvevő szervezetek 60 százalékában nem foglalkoznak a pletykálkodás következményeivel vezetői szinten sem.

\section{A kutatás korlátai}

A kutatás egyik korlátja finanszírozási probléma, ami miatt korlátozott mértékben sikerült válaszadókat gyüjteni. A mintaszámon túl olyan eseteket nem tudtunk kérdöíves formában lekérdezni, amelyek arról tanúskodnának, hogy mi történik akkor, ha vélelmezett, de nem tudott az információ valóságtartalma, akár az átadó, vagy az át- vevő részéről. Ezeknek a speciális szituációknak a feltárása kvalitatív eszközöket igényel. Korlátként tekinthető minden olyan tényező, ami a kérdőíves felmérések sajátja, nevezetesen a megkérdőjelezhető őszinteség, a beazonosíthatósággal kapcsolatos félelmek, az esetleges félreértelmezett kérdések. A kutatók minden törekvése ellenére is fennállhatnak ezek az esetlegesen eredményt befolyásoló tényezők. A kutatás további lépései során igyekszünk a mintaszám növelésével a kutatás korlátait csökkenteni.

\section{Felhasznált irodalom}

Azudin, N., Ismail, M.N. \& Taherali, Z. (2009). Knowledge sharing among workers: a study on their contribution through informal communication in Cyberjaya. Malaysia, Knowledge Management \& E-Learning: An International Journal, 1(2), 139-162.

https://doi.org/10.34105/j.kmel.2009.01.011

Awazu, Y. (2004). Informal network players, knowledge integration, and competitive advantage. Journal of Knowledge Management, 8(3), 62-70. https://doi.org/10.1108/13673270410541042

Bárczi, G. \& Országh, L. (2016). A magyar nyelv értelmezö szótára (CD-ROM). Budapest: Arcanum Adatbázis Kft.

Baksa, M. \& Báder, N. (2020). A tudáskérés és tudásmegosztás feltételei - egy szervezeti tudáshálózat elemzése. Vezetéstudomány, 51(1), 32-45. https://doi.org/10.14267/VEZTUD.2020.01.03

Bencsik, A. (2015). Tudásmenedzsment elméletben és gyakorlatban. Budapest: Akadémiai Kiadó.

Bencsik, A. \& Juhász, T. (2015). The Practice of Successful Mentoring in the Dimension of Hungarian Organizations. Science Journal of Business and Management, 3(2), 1-7. https://doi.org/10.11648/j.sjbm.s.2015030101.11

Bencsik, A. \& Juhász, T. (2018). Tudásorientált szervezetek értékítélete a bizalom gazdasági hatásairól. Vezetéstudomány, 49(1), 30-39. https://oi.org/10.14267/VEZTUD.2018.01.04

Bennett, J. (2014). The Healthy Workplace Model: Evidence-Based Tools for Resilience. Retrieved from https://organizationalwellness.com/blogs/blog/ healthy_workplace_model

Boer, N. (2005). Knowledge Sharing within Organizations A situated and relational Perspective. ERIM Electronic Series Portal. Retrieved from http://hdl.handle. net/1765/1

Bresnen, M., Edelman, L., Newell, S., Scarbrougha, H. \& Swana, J. (2003). Social practices and the management of knowledge in project environments. International Journal of Project Management, 21(3), 157-166. https://doi.org/10.1016/S0263-7863(02)00090-X

Csillag, S. Csizmadia, P. Hidegh, A. \& Szászvári, K. (2020). A kicsi szép? Tanulás és fejlődés a kisvállalkozásokban. Vezetéstudomány, 51(1), 2-15. https://doi.org/10.14267/VEZTUD.2020.01.01

Edvinsson, L. (2006). Aspects on the city as a knowledge tool. Journal of Knowledge Management, 10(5), 6-13. https://doi.org/10.1108/13673270610691134 
Ellwardt, L., Steglich, Ch. \& Wittek, R. (2012). The coevolution of gossip and friendship in work-place social networks. Social Networks, 34(4), 623-633. https://doi.org/10.1016/j.socnet.2012.07.002

Ellwardt, L., Labianca, G. J. \& Wittek, R. (2012). Who are the objects of positive and negative gossip at work? A social network perspective on workplace gossip. Social Networks, 34(2), 193-205.

https://doi.org/10.1016/j.socnet.2011.11.003

Ellwardt, L., Wittek, R. \& Wielers, R. (2012). Talking About the Boss, Effects of Generalized and Interpersonal Trust on Workplace Gossip. Group \& Organization Management, 37(4), 529-541.

https://doi.org/10.1177/1059601112450607

Eraut, M. (2000). Non-formal learning and tacit knowledge in professional work. British Journal of Educational Psychology, 70(1), 113-136.

https://doi.org/10.1348/000709900158001

Feinberg, M., Willer, R. \& Schultz, M. (2014a). Gossip and Ostracism Promote Cooperation in Groups. Psychological Science, 25(3), 656-664. https://doi.org/10.1177/0956797613510184

Feinberg, M., Willer, R., Stellar, J.E. \& Keltner, D. (2014b). Gossip and Ostracism Solve the Cooperation Problem. Psychological Science, 25(3), 1015-1030. https://doi.org/10.1037/a0026650

Feinberg, M. \& Willer, R. (2010). The Good of Gossip? The Benefits of this Unlikely Prosocial Behavior. Berkeley: Department of Psychology University of California.

Ferris, G. R. \& Judge, T. A. (1991). Personnel/human resources management: A political influence perspective. Journal of Management, 17(2), 447-488. https://doi.org/10.1177/014920639101700208

Georganta, K., Panagopoulou, E. \& Montgomery, A. (2014). Talking behind their backs: Negative gossip and burnout in Hospitals. Burnout Research, 1(2), 7681.

https://doi.org/10.1016/j.burn.2014.07.003

Ives, W., Torrey, B. \& Gordon, C. (2003). Knowledge Management: an emerging discipline with a long history. Journal of Knowledge Management, 1(1), 269-274.

https://doi.org/10.1108/EUM0000000004582

Jaeger, M. E., Skelder, A. A., \& Rosnow, R. L. (1998). Who's up on the low down: Gossip in interpersonal relationships. In B. H. Spitzberg \& W. R. Cupach (Eds.), The dark side of close relationships (pp. 103117). Mahwah, NJ: Lawrence Erlbaum.

Krauthammer (2012). Informal learning in organisations, An exploration. A research reportprovided by Krauthammer. Noordwijk, Netherland.

Krogh, G., Nonaka, I. \& Nishiguchi, T. (2000). Knowledge Creation: A Source of Value. London: Palgrave Macmillan.

Kuo, Ch, Chang, K., Quinton, S., Lu, Ch., \& Lee, I. (2015). Gossip in the workplace and the implications for HR management: a study of gossip and itsrelationship to employee cynicism, The International Journal of Human Resource Management, 26(18), 2288-2307, https://doi.org/ doi: 10.1037/a002665010.1080/0958519 2.2014.985329

Leonardi, P.M. (2015). Ambient Awareness and Knowledge Acquisition: Using Social Media to Learn "Who Knows What" and "Who Knows Whom". MIS Quarterly, 39(4), 747-762.

https://doi.org/10.25300/MISQ/2015/39.4.1

Lorincová, S. (2018). Human resource and corporate culture: Gender-based differences in the assessment. Central European Journal of Labour Law and Personnel Management, 1(1), 28-45. https://doi.org/10.33382/cejllpm.2018.01.03

Millikin, J. W. \& Johnson, S. M. (2008). Telling Tales. Journal of Family Psychotherapy, 11(1), 73-79. https://doi.org/10.1300/J085v11n01_05

Mindennapi Pszichológia (2018). A pletyka jótékony hatásai. Letöltés: http://mipszi.hu/hir/120503- pletyka-jotekony-hatasai

Nonaka, I. (1994). A dynamic theory of organizational knowledge creation. Organization Science, 5(1), 14-37. https://doi.org/10.1287/orsc.5.1.14

Novotna, M. \& Volek, T. (2018). Efficiency of production factors in the EU. DETUROPE-The Central European Journal of Regional Development and Tourism, 10(2), 147-168. Retrieved from http://www.deturope.eu/img/ upload/content_60007194.pdf

Nunes, M.B., Annansingh, F. \& Eaglestone, B. (2006). Knowledge management issues in knowledge-intensive SMEs. Journal of Documentation, 62(1), 101-119. https://doi.org/10.1108/00220410610642075

Obadovics, J. Gy. (2006). Matematika. Budapest: Scolar Kiadó.

Parker, C.B. (2014). Stanford research: Hidden benefits of gossip, ostracism. Stanford: Stanford Report.

Probst, G., Raub, S. \& Romhardt, K. (2006). Wissen Managen Wie Unternehmen ihre wertvollste Ressource optimal nutzen. Wiesbaden: Gabler GmbH.

Reagans, R. \& McEvily, B. (2003). Network Structure and Knowledge Transfer: The Effects of Cohesion and Range. Administrative Science Quarterly, 48(2), 240267. https://doi.org/10.2307/3556658

Rosnow, R. L. (2001).: Rumor and gossip in interpersonal interaction. In R. M. Kowalski (Ed.), Behaving Badly (pp. 203-232). Washington, DC: American Psychological Association.

Rudnickia, K., De Backera, C. J. S. \& Declerckb, C. (2019). The effects of celebrity gossip on trust are moderated by prosociality of the gossipers. Personality and Individual Differences, 143, 42-46.

https://doi.org/10.1016/j.paid.2019.02.010

Sommerfeld, R.D., Krambeck, H.J., Semmann, D. \& Milinski, M. (2007). Gossip as an alternative for direct observation in games of indirect reciprocity. PNAS, 104(44), 17435-17440.

https://doi.org/10.1073/pnas.0704598104

Sturdy, A., Schwarz, M. \& Spicer, A. (2006). Guess who's coming to dinner? Structures and uses of liminality in strategic management consultancy. Human Relations, 
59(7), 929-960.

https://doi.org/10.1177/0018726706067597

Swap, W., Leonard, D.A., Shields, M. \& Abrams, L. (2001). Using Mentoring and Storytelling to Transfer Knowledge in the Workplace. Journal of Management Information Systems, 18(1), 95-114.o. https://doi.org/10.1080/07421222.2001.11045668

Szvetelszky, Zs. (2017): Rejtett szervezetek - Az informális kommunikáció hatalma. Budapest: Typotex Elektronikus Kiadó Kft.

Szvetelszky, Zs. (2010). A pletyka pszichológiája (PhDdisszertáció). Pécsi Tudományegyetem, Pécs.

Taminiau, Y., Smit, W. \& Lange, A. (2009). Innovation in Management Consulting Firms through Informal Knowledge Sharing. Journal of Knowledge Management, 13(1), 42-55. https://doi.org/10.1108/13673270910931152

Tassiello, V., Lombardi, S. \& Costabile, M. (2018). Are we truly wicked when gossiping at work? The role of valence, interpersonal closeness and social awareness. Journal of Business Research, 84(3), 141-149. https://doi.org/10.1016/j.jbusres.2017.11.013

Thibaut, J. W., \& Kelley, H. H. (1959). The social psychology of groups. New York: John Wiley \& Sons.

Truran, W. R. (1998). Pathways for knowledge: How companies learn through people. Engineering Management Journal, 10(4), 15-20. https://doi.org/10.1080/10429247.1998.11415003

Vajda, P. (2007). Dealing with workplace gossip. Retrieved from https://www.management-issues. com/opinion/4402/dealing-with-workplacegossip/

Volek, T. \& Novotna, M. (2016). Labour productivity as a factor of sector competitiveness. In The 10th International Days of Statistics and Economics (pp. 1997-2006). Sept. 8-10., Prague. 1997-2006. Retrieved from https://pdfs.semanticscholar. org/0f17/a52025f4fb042c5c29a313b820a0cb922815. pdf

Wabwezi, A. (2011). The role of knowledge sharing in fostering innovation in higher education: a case study of Tallinn University (Master thesis). Høgskolen i Oslo. Retrieved from http://hdl.handle. net/10642/988

Werr, A. \& Stjernberg, T. (2003). Exploring management consulting firms as knowledge systems. Organization Studies, 24(6), 881-908. https://doi.org/10.1177/0170840603024006004

Wilkie, D. (2019). Workplace Gossip: What Crosses the Line? Society for Human Resource Management. Retrieved from https://www.shrm.org/ resourcesandtools/hr-topics/employee-relations/pages/ office-gossip-policies.aspx

Yakel, E. (2000): Knowledge Management: The Artchivist's and Records Manager's Perspective. Information Management Journal, 37(3), 24.

Yi, J. (2015). A Measure of Knowledge Sharing Behavior: Scale Development and Validation. Knowledge Management Research \& Practice, 7(1), 65-81. https://doi.org/10.1057/kmrp.2008.36 